\title{
Hypoglycaemia and cerebral malaria
}

\author{
C.F. Kiire
}

Department of Medicine, University of Zimbabwe, P.O. Box A 178, Avondale, Harare, Zimbabwe

\begin{abstract}
Summary: A patient with severe hypoglycaemia complicating cerebral malaria is reported. No other recognized cause of hypoglycaemia was detected during life or at autopsy. This case adds to the existing evidence that, through several possible mechanisms, cerebral malaria can give rise to life-threatening hypoglycaemia.
\end{abstract}

\section{Introduction}

It is not generally realized that hypoglycaemia is a complication of cerebral malaria (Fitz-Hugh et al., 1944; Devakul, 1980; White et al., 1983). A further patient with cerebral malaria complicated by spontaneous hypoglycaemia is hereby reported.

\section{Case report}

A 45 year old African male peasant farmer was admitted to Harare Central Hospital in coma. According to relatives he had been well until three days before admission when he complained of generalized weakness and malaria. A day later he developed a fever associated with rigors. He was given oral chloroquine but apparently vomited most of it. His level of consciousness gradually deteriorated and by the time of his admission he was unconscious.

On physical examination he was a very ill patient who was deeply comatose. He was sweating profusely. $\mathrm{He}$ had a temperature of $38.5^{\circ} \mathrm{C}$. The pulse rate was $128 /$ minute and blood pressure $150 / 90 \mathrm{~mm} \mathrm{Hg}$. The liver and spleen were not palpable. His neck was soft and there were no localizing signs on neurological examination.

A blood slide for malarial parasites was strongly positive for Plasmodium falciparum with 44 ring forms per 300 white blood cells. A random blood sugar using the glucose oxidase method revealed a glucose level of $1.0 \mathrm{mmol} / \mathrm{l}$. This was re-checked several times and similar results were obtained. The cerebro spinal fluid results were normal apart from a reduced sugar level, which was expected in the light of the low blood glucose level. A diagnosis of cerebral malaria complicated by hypoglycaemia was therefore made.

Correspondence: C.F. Kiire, M.B., Ch.B., M.Med., M.R.C.P. (UK).

Accepted: 22 October 1985
Fifty $\mathrm{ml}$ of $50 \%$ dextrose was immediately given by slow intravenous injection followed by $10 \%$ dextrose infused at a rate of $10 \mathrm{~g}$ glucose per hour. A chloroquine infusion consisting of $5 \mathrm{mg} / \mathrm{kg}$ body weight of chloroquine diluted in normal saline to run over 4 hours was started. A repeat blood glucose test 2 hours later revealed a blood glucose concentration of only $2.2 \mathrm{mmol} / \mathrm{l}$. The patient was therefore given a further $50 \mathrm{ml}$ of $50 \%$ dextrose by slow intravenous injection but died 3 hours after admission.

This probably represents yet another example of chloroquine failing to save life, and in retrospect quinine by infusion should have been used instead. At autopsy no glycogen was found in the liver.

\section{Discussion}

The incidence of hypoglycaemia in severe falciparum malaria is not known. White et al. (1983) found it in $8 \%$ in their patients with cerebral malaria. Hypoglycaemia is often missed in such patients as the deepening coma or alteration in the level of consciousness is usually attributed to cerebral malaria. It is therefore likely that hypoglycaemia contributes significantly to the high mortality of cerebral malaria which ranges from 20 to $50 \%$ (Warrell et al., 1982).

White et al. (1983) found that hypoglycaemia in their patients was associated with hyperinsulinaemia. They used quinine for treating their patients who had severe chloroquine resistant falciparum malaria and found a highly significant correlation between plasma quinine and insulin at the time of hypoglycaemia. All but one of their 17 patients had detectable plasma quinine concentrations at the time of hypoglycaemia. Migasena (1983) reported six patients (5 pregnant) who developed hypoglycaemia between 18 and 38 hours after the start of quinine therapy. So in these two studies only one patient out of 23 was not receiving 
quinine when hypoglycaemia developed. Quinine is known to stimulate insulin secretion in vivo, which would suggest that quinine was a major stimulating factor for insulin hypersecretion in their patients.

Another explanation for the occurrence of hypoglycaemia may be the consumption of glucose by the parasitized cells. In animal malarias parasitized red cells consume 75 times more glucose than uninfected red cells, with lactate as the end product of glycolysis (Sherman, 1979).

Lactic acidosis may result also from high lactate production by parasites, high catecholamine excretion and decreased tissue perfusion. This can lead to a decrease in hepatic uptake of glucose and impaired gluconeogenesis (Mallis et al., 1972).

Endotoxaemia has been reported in falciparum

\section{References}

DEVAKUL, K. (1960). Sugar metabolism in malaria. Transactions of the Royal Society of Tropical Medicine and Hygiene, 54, 87.

FITZ-HUGH, T., PEPPER, D.S. \& HOPKINS, H.U. (1944). The cerebral form of malaria. Bulletin of the United States Army Medical Department, 83, 38.

FRANCES, W.E. JR. \& WATSON, J.G. (1977). Hypoglycaemia following endotoxin administration in animals with liver damage. Proceedings of the Society of Experimental Biology and Medicine, 155, 833.

MALLIS, E.B., AOOKI, T.T., TOEW, C.J., FELLIG, P., CONNON, J.J., KYNER, J., HUCKABLE, W.E. \& KAHILL, G.F. (1972). Amino acid metabolism in lactic acidosis. American Journal of Medicine, 52, 474.

MIGASENA, S. (1983). Hypoglycaemia in falciparum malaria. Annals of Tropical Medicine and Parasitology, 77, 323.

SANDFORD, J.P., BARNETT, J.A. \& GOTT, C. (1960). A mechanism of glycogenolytic action of bacterial endotoxin. Journal of Experimental Medicine, 112, 97. malaria (Tubbs, 1980). Endotoxin is also known to stimulate insulin secretion (Yelich \& Filkins, 1980) as well as inhibit gluconeogenesis (Frances \& Watson, 1977) and deplete glycogen (Sandford et al., 1980).

The pathophysiology of hypoglycaemia complicating cerebral malaria is very complex. The major aetiological factors appear to include acidosis, decreased tissue perfusion, endotoxaemia, hyperinsulinaemia, impaired glucose production by the liver, and, above all, quinine therapy. It should be emphasized that hypoglycaemia is an important complication of falciparum malaria which may be unsuspected and untreated because the patient's neurological symptoms have been attributed solely to cerebral malaria. Blood glucose should be monitored in all cases of severe falciparum malaria.

SHERMAN, I.W. (1979). Biochemistry of Plasmodium (malarial parasites). Microbiological Reviews (Washington), 43, 453.

TUBBS, H. (1980). Endotoxin in human and murine malaria. Transactions of the Royal Society of Tropical Medicine and Hygiene, 74, 121.

WARRELL, D.A., LOOAREESUMAN, S., WARRELL, M.J., KASEMSARIN, P., INTEPRASERT, R., BUNNAG, D. \& HARITINASUTA, T. (1982). Dexamethasone proves de-O leterious in cerebral malaria: a double blind trial in 100 comatose patients. New England Journal of Medicine, 306 313.

WHITE, N.J., WARRELL, D.A., CHANTHAVAMICH, P., LOOAREESUMAN, S., WARRELL, M.J., KRISHNA, S., WILLIAMSON, D.H. \& TURNER, H.C. (1983). Severe hypoglycaemia and hyperinsulinemia in falciparum malaria. New England Journal of Medicine, 309, 61.

YELLICH, M.R. \& FILKINS, J.P. (1980). Mechanism of hyperinsulinemia in endotoxicosis. American Journal of Physiology, 239, E156. 